\title{
THE INTRAVENOUS INJECTION OF BOVINE CRYSTALLINE PANCREATIC DESOXYRIBONUCLEASE INTO PATIENTS ${ }^{1}$
}

\author{
By ALAN J. JOHNSON, PAULINE R. GOGER, AND WILliAM S. TILlETT
}

(From the Department of Medicine, New York University College of Medicine, and the Third (NYU) Medical Division, Bellevue Hospital, New York, N. Y.)

(Submitted for publication May 3, 1954 ; accepted August 4, 1954)

In connection with investigations of streptococcal desoxyribonuclease contained in Varidase, 2 comparative observations have included the intravenous administration of crystalline pancreatic desoxyribonuclease in patients (1).

Crystalline pancreatic desoxyribonuclease (referred to throughout this article as PD) has been isolated from beef pancreas and its general properties determined (2-4). The crystalline material $^{8}$ made according to the methods of Kunitz, has been employed in this study.

The results to be described center primarily around the intravenous injection of PD into patients. In addition, observations have been made on the renal excretion and clearance of $\mathrm{PD}$, its diffusion into various extravascular areas and the effect of intrathecal injections in adults and children with and without meningitis. Extensive clinical and laboratory examinations have been made for evidence of toxicity.

The categories of the studies may be listed as: a) Toxicity studies following intravenous and intrathecal injections; b) blood levels following intravenous infusions; c) "naturally" occurring inhibitor for PD (in the general circulation); d) renal excretion and clearance; e) diffusion into the peritoneal and pleural fluids, wound exudates, bronchial secretions and cerebro-spinal fluid; and f) the development of specific antibodies.

A discussion of the potential therapeutic implications of PD follows.

1 This study was supported by grants from the $\mathrm{Na}$ tional Institutes of Health, U. S. Department of Health, Education, and Welfare, and Lederle Laboratory Division, American Cyanamid Company.

2 Streptokinase-Streptodornase, Varidase, Lederle Laboratories, Pearl River, N. Y.

s Supplied by Worthington Chemical Co., Freehold, New Jersey.

\section{MATERIALS AND METHODS}

\section{Enzyme substrate}

A 0.15 per cent solution of purified calf thymus desoxyribonucleic acid 4 (DNA) was prepared by adding the dried sodium thymonucleate to $M / 40$ veronal buffer pH 7.5, and agitating in a shaking machine until the DNA went into solution. After shaking, the solution was heated at $56^{\circ} \mathrm{C}$. for 5 to 25 hours until residual depolymerase activity was destroyed. Further heating was used (a) to reduce the viscosity to a specific viscosity of about 5 to 7.0 (4.0 centipoise to 5.6 centipoise) and $(b)$ to inhibit the "reactivity" of the DNA. Inasmuch as the assay value for a standard control solution of desoxyribonuclease could be decreased by prolonged heating of the DNA substrate used for its assay, it seemed likely that the "reactivity" of the DNA was controlled by this heating. This decrease occurred without an apparent change in the viscosity of the DNA. In order to obtain consistent and reproducible results with this enzyme assay, it proved to be obligatory to control these three variables: the stability, viscosity, and "reactivity" of the substrate. $\mathrm{Mg}^{++}$was added to the DNA solution after heating to a final concentration of $.003 \mathrm{M}$.

\section{Desoxyribonuclease assay}

The assay for desoxyribonuclease activity (5) was modified as follows : a) $0.1 \mathrm{ml}$. or $0.2 \mathrm{ml}$. of sample was used interchangeably as required, for optimum enzyme concentration in the assay ; $b$ ) recovery experiments with $\mathrm{PD}$ in neopeptone buffer, urine, and cerebro-spinal fluid indicated a linear relationship between enzyme concentration and decrease in viscosity of the DNA substrate from 0.2 to 0.8 viscosity units in 10 minutes. However, PD in inhibitor-free sera could not be measured accurately unless the reduction in viscosity was at least 0.4 viscosity units in 10 minutes; c) the assay was performed for as long as necessary (15 to 90 minutes) to obtain a readily measurable, sustained, linear fall in viscosity.

Assays on PD in urine were complicated by the adsorption of small amounts of PD on phosphate crystals. Therefore, prior to assay, crystal formation in the samples of urine was minimized by incubation in a $35^{\circ} \mathrm{C}$.

4 The desoxyribonucleic acid was supplied by Lederle Laboratories, Pearl River, N. Y. 
waterbath for 5 to 10 minutes and by adjusting the pH to 6.5 with $\mathrm{N} / 10 \mathrm{HCl}$.

Neopeptone buffer (6) was used to dilute the samples containing PD for assay. A 1 per cent solution of human serum albumin' in physiological saline was used to dilute the enzyme prior to injection. Saline-albumin was found to be an excellent stabilizing agent for dilute enzyme preparations ( 20 micrograms per $\mathrm{ml}$.)

\section{$P D$ inhibitor}

One-tenth of one $\mathrm{ml}$. of a standard solution containing 80 units of $P D$ per $\mathrm{ml}$. was added to $0.9 \mathrm{ml}$. of fresh serum (or serum stored when fresh at $-20^{\circ} \mathrm{C}$.) to produce a final concentration of 8 units of PD per $\mathrm{ml}$. of serum. The mixture was incubated at room temperature for 15 minutes, with gentle mixing by inversion every 5 minutes. The mixture was then assayed and a recovery of less than 7.7 units of $\mathrm{PD}$ was considered evidence of inhibition. A further check on the method was made possible because the reversible, immunologically non-specific inhibition was removed by heating the mixture in a water bath at $35^{\circ} \mathrm{C}$. for 5 to 10 hours. At the end of the heating period, recovery of the original 8 units from the sera was obtained.

\section{$P D$ antibody}

The viscosimetric antibody determination was performed as previously described for SD (7), except for the fact that the sera were heated at $56^{\circ} \mathrm{C}$. for 2 to 4 hours prior to incubation with the enzyme solution.

\section{Proteolytic activity}

Fibrinolysis and fibrinogenolysis were used to estimate the proteolytic activity of the PD. Various concentrations of $P D$, from $0.1 \mathrm{mgm}$. per $\mathrm{ml}$. to $100 \mathrm{mgm}$. per $\mathrm{ml}$. were mixed with a solution of fibrinogen and clotted with thrombin to produce a standard clot $(5,8)$. Lysis of the clots in the tubes with PD before those in the controls was considered evidence of proteolytic activity. The control clots were stable for at least 24 hours. Fibrinogenolysis was determined by incubating the fibrinogen with comparable amounts of PD for four hours, after which (a) thrombin was added to produce a clot, or (b) 10 per cent trichloracetic acid was added to facilitate testing for acid-soluble tyrosine in the supernatant. Absence of clot formation or an increase in acidsoluble tyrosine in the supernatant indicated fibrinogenolysis. Tyrosine was determined as previously described (8).

\section{Feulgen stain}

The Feulgen stain was carried out on samples that were smeared on carefully washed slides and air-dried without fixation (9).

\footnotetext{
S Normal serum albumin (human) salt-poor, U.S.P., Cutter Laboratories, Berkeley, California.
}

\section{Samples}

Merthiolate, $1: 10,000$ was used as a preservative in all samples unless otherwise indicated.

Serum: Fresh, whole blood was allowed to clot in new plastic 7 centrifuge tubes, centrifuged within 1 hour and the decanted serum stored at $-20^{\circ} \mathrm{C}$.

Plasma: Plasma was obtained using Amberlite 1R-100 8 and Amberlite 1R-120,8 (10), respectively. This was done because citrate or oxalate inhibits $\operatorname{PD}(6,11)$. Furthermore, preliminary studies in this laboratory have shown that relatively low concentrations of heparin ${ }^{\circ}$ also inhibit PD.

Sputum: Sputum samples were centrifuged at 5,000 to $10,000 \mathrm{rpm}$ and the supernatant used for assay. When high viscosity sputum made pipetting of the supernatant inaccurate, the sputum was mixed thoroughly, diluted 1:2 with saline, then centrifuged, and the supernatant used for assay.

\section{Clinical-pathological laboratory determinations}

Conventional methods were used to determine the red blood count, white blood count and differential on whole blood and spinal fluid, as well as the hemoglobin and hematocrit, the bleeding time (Duke method), coagulation time (Lee-White) and the prothrombin time (Quick method with Simplastin 10) $(12,13)$. Preparations for the demonstration of the Lupus erythematosus cell ( $L-E$ cell) were made by the heparin (14) and defibrination techniques (15).

The total protein content of the cerebro-spinal fluid was determined by a modified tyrosine method (8), and by a modified sulfosalicylic acid method (16) and checked by the Kjeldahl technique (17). The cerebrospinal fluid sugar was analyzed by the Folin-Wu method (18).

\section{RESULTS}

\section{Toxicity studies following intravenous injection of $P D$ into patients}

Crystalline pancreatic desoxyribonuclease (PD) has been injected in 65 adults and 45 children. ${ }^{11}$ The intravenous dosage was successively increased

- Merthiolate (Thimerosal), Eli Lilly and Co., Indianapolis, Indiana.

' Lusteroid Container Corp., Inc., Maplewood, New Jersey.

8 Amberlite 1R-100 and Amberlite 1R-120, Rohm and Haas Co., Philadelphia, $\mathrm{Pa}$.

- Heparin, sodium salt, Connaught Medical Research Laboratories, Toronto, Ontario, Canada.

10 Simplastin, Chilcott Laboratories, Morris Plains, New Jersey.

11 The studies in children were made on the Pediatric Service of Dr. L. Emmett Holt. The interest and advice of Dr. Holt and Dr. Edith Lincoln have proved invaluable. 
from 10 units to $2,000,000$ units per injection. Sixteen patients received more than 100,000 units but less than 1 million, and 41 patients received $1,000,000$ to $3,000,000$ units. There was no evidence of systemic toxicity in the patients receiving the PD by intravenous injections or by other parenteral routes, including intrathecal. The criteria for toxicity were based upon symptomatology, temperature, pulse, blood pressure, urine analysis, as well as the red blood count, hemoglobin, hematocrit, white blood count and differential, and the bleeding time, coagulation time, prothrombin time, and "Lupus erythematosus (L. E.) cell" preparations.

Special attention was given to the speed of injection in order to prevent a non-specific foreign protein reaction. The injection time was varied from 2 minutes to several hours at each dosage level. No reactions occurred.

The crystalline PD was also tested for contamination by other potentially toxic proteins, notably trypsin inasmuch as Kunitz has shown that trypsinogen and PD can be precipitated from an acid extract of beef pancreas (3) with 20 and 40 per cent saturated ammonium sulfate, respectively. Several preparations of PD were tested for tryptic activity by incubation in various concentrations with fibrin and fibrinogen. No measurable proteolytic activity was seen. Since trypsin accelerates prothrombin conversion to thrombin and has been observed to shorten the coagulation time and cause thrombosis $(19,20)$ in vivo, freshly drawn whole blood was taken in a siliconed syringe, ${ }^{12}$ measured by siliconed pipettes, and mixed in a Lee-White tube with $0.1 \mathrm{ml}$. of various concentrations of PD. No acceleration in the clotting time was observed. Furthermore, no local thromboses have been noted following the injection of PD intravenously.

Since it has been suggested that the L.E. cell phenomenon may be potentiated by increased serum desoxyribonuclease or destruction of an intracellular inhibitor $(21,22)$, L.E. cell preparations were carried out at various time intervals following the intravenous injection of $1,000,000$ units of PD, by both the heparin and clot methods on blood from normal individuals who had high, medium, and low serum levels of PD.

\footnotetext{
12 DC 200, Dow-Corning Corp., Midland, Mich.
}

There was no evidence of L.E. cell transformation in these in vivo studies, thus corroborating the earlier in vitro work of Kurnick, Pariser, Schwartz, Lee, and Irvine (23).

\section{Toxicity studies following the intrathecal injec- tion of P.D into patients}

Intrathecal injections were made in normal individuals and in patients with meningitis in amounts ranging from 10 units to 500,000 units in a single injection. Approximately 180 injections have been administered to 38 patients; 16 of these were children. About 80 per cent of the injections ranged from 25,000 to 50,000 units per injection. The tests for toxicity were those enumerated above, and in addition, the cerebro-spinal fluid total-cell count, white blood count, differential, total protein and sugar. Estimation of the cerebro-spinal fluid pressure and the Queckenstadt maneuver were also routine.

Fifteen normal adults were given PD intrathecally from six different batches of PD. Two received 25,000 units of $P D$ intrathecally from lots $\mathrm{A}$ and $\mathrm{B}$, respectively. The only reaction was a rise in the white blood count of 10 to 15 cells in the cerebro-spinal fluid, largely lymphocytes. Three patients received 50,000 units from lot $C$ (processed in a different manner from the other batches). Each of the three patients had a mild temperature rise of 1 to $2^{\circ} \mathrm{F}$. with mild headache, a rise in cerebro-spinal fluid white blood cells to nearly 2,000 cells and a rise in cerebro-spinal fluid pressure to 200 to $250 \mathrm{~mm}$. of water. The symptoms disappeared in two days and the cerebro-spinal fluid returned to normal in 3 to 4 days. This batch of PD was subsequently discarded. Two patients received 50,000 units of lot $\mathrm{E}$, and three patients received 50,000 units of lot $\mathrm{F}$ without apparent toxic effect other than a transient increase in the cerebrospinal fluid white blood cell count to 30 to 50 cells (90 per cent lymphocytes).

One vial of lot $\mathrm{D}$ had been mixed several weeks before it was injected and contained a very small stringy precipitate. About 8 to 10 hours following the intrathecal injection of lot $\mathrm{D}$ in two patients, each of them had a one degree rise in temperature with a sharp rise in white blood cells in the cerebro-spinal fluid (to nearly 1,000 cells, 95 
per cent polys), and a $1+$ Pandy reaction. The cerebro-spinal fluid returned to normal in 3 days. Two additional patients received freshly mixed preparations of the same lot $\mathrm{D}$. No reaction occurred except a slight rise in the white blood cells of the cerebro-spinal fluid to 10 to 15 lymphocytes. A vial of freshly mixed preparation of the same lot $\mathrm{D}$ above was shaken vigorously until a small stringy precipitate was produced, and the contents of the vial were injected intrathecally. Once again, a mild febrile reaction occurred with a sharp rise in the white blood cells of the cerebrospinal fluid. The enzyme titer of each of the vials of lot D, at the time of injection, was found to be the same, irrespective of whether the samples were fresh, old, or agitated. The contents of each of the vials was cultured and was found to be sterile. Since the toxic reaction occurred when the stringy precipitate was seen, and did not occur when the same lot free of precipitate was used, the toxicity was assumed to be due to denatured protein.

Various lots of PD (except lot C) were given intrathecally in repeated injections of 50,000 to 100,000 units to 15 patients with pyogenic and 3 patients with tuberculous meningitis. Toxic reactions were not observed. The pyogenic meningitides included three cases due to $H$. influenzae, three cases due to $D$. pneumoniae, seven cases due to meningococcus, and two cases due to staphylococcus aureus. Occasionally, the cerebro-spinal fluid pressure in a normal, or meningitic patient has been found to be low following the injection of the enzymes. This effect was transient and the reasons have not been apparent. A definite increase in pressure, possibly attributable to the enzyme has been seen just once. A six months old infant with E. coli meningitis was given 200,000 units of PD intrathecally, 300,000 units the following day, 400,000 units the next, and 500,000

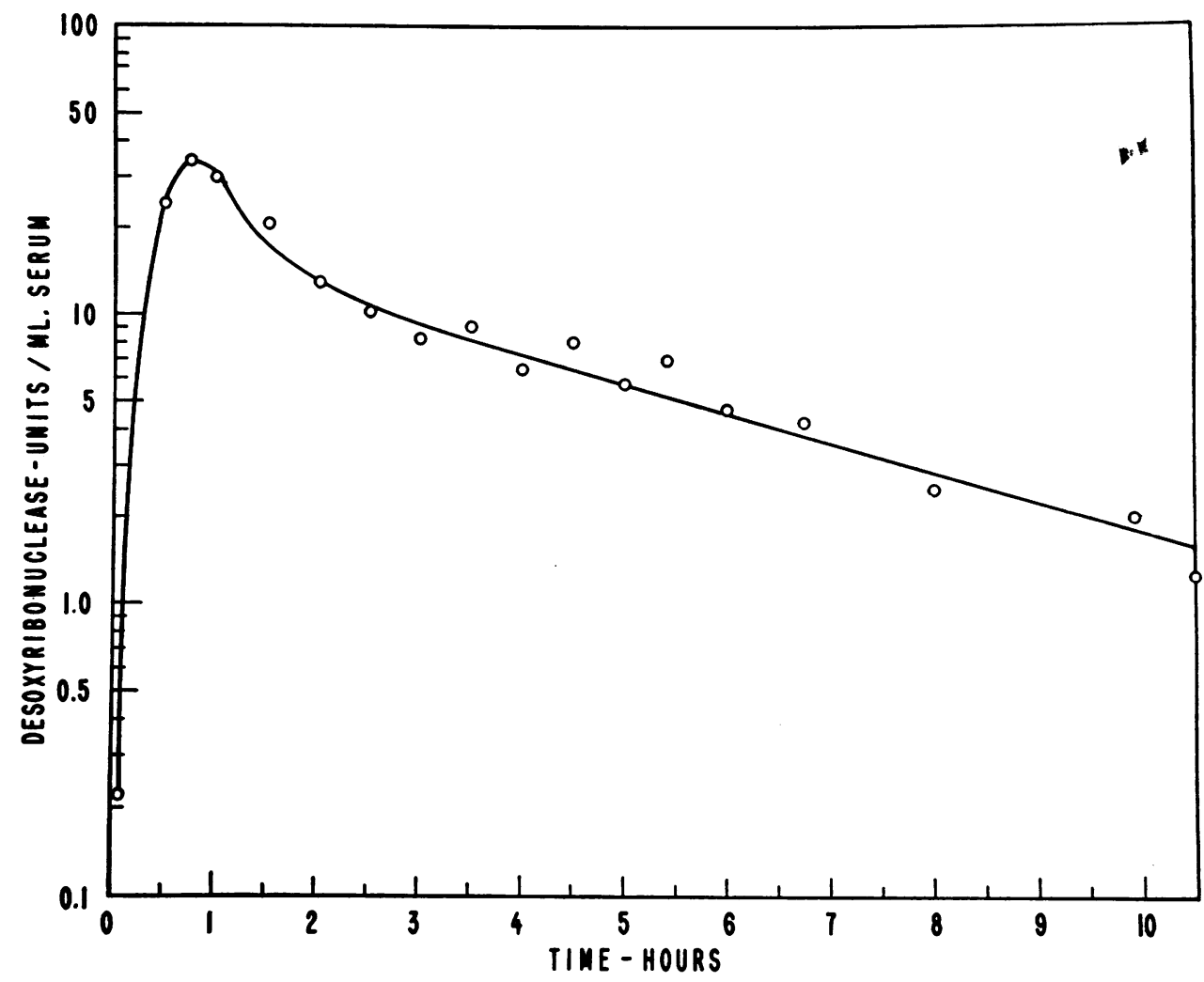

Fig. 1. Semi-Log Plot of the Average Serum Levels of PD for Eight Patients Following THE RAPID INTRAVENOUS INFUSION OF 1,000,000 Units OF PD

The initial level represents an average of the endogenous serum levels. 
units on the fourth day. The cerebro-spinal fluid pressure rose transiently to about $300 \mathrm{~mm}$. of water. On the other hand, 100,000 units of PD were administered daily, intrathecally for nearly 14 days to another child (two years old), with tuberculous meningitis, without an increase in cerebro-spinal fluid pressure.

Six patients received repeated injections of large amounts of $\mathrm{PD}$ over a prolonged period. Successive injections were given intravenously and/or intrathecally for periods ranging from two days to two months, making a total of more than $60,000,000$ units in 83 intravenous injections, 109 intrathecal injections and two endobronchial instillations. Two children with tuberculous meningitis received very large amounts of $P D$. One received about $23,000,000$ units in 27 intravenous injections and 2,000,000 units in 18 lumbar (intrathecal) and 25 intra-ventricular injections over a period of one and one-half months. The other was given more than $11,000,000$ units in 24 intravenous injections and nearly 3,000,000 units in 24 lumbar and 20 intra-ventricular injections over a comparable period. There was no systemic or local toxicity evident.
Blood levels of PD following intravenous injections

Serial blood determinations were made on 20 patients following a single injection of $1,000,000$ units of $\mathrm{PD}$. The average curve for eight patients (Figure 1) indicates a serum level of 30 units of $\mathrm{PD}$ per $\mathrm{ml}$. about one hour after the termination of the infusion, with a range of 18 to 50 units.

The maximum serum level following intravenous injection fell progressively for 8 to 12 hours, when it tended to level off. A level of 0.5 to 1.0 unit of desoxyribonuclease was found in the serum for 24 to 48 hours following the injection. A low initial level of desoxyribonuclease activity was found in the serum, apparently due to endogenous DNase as previously described (2426). The level of endogenous DNase found in normal individuals by the technique used was approximately 0.05 unit.

The naturally occurring inhibitor for PD in the circulating blood was found to be destroyed by heating at $35^{\circ} \mathrm{C}$. for 5 to 10 hours. PD remained stable during this heating process. Consequently, when serum from a patient following

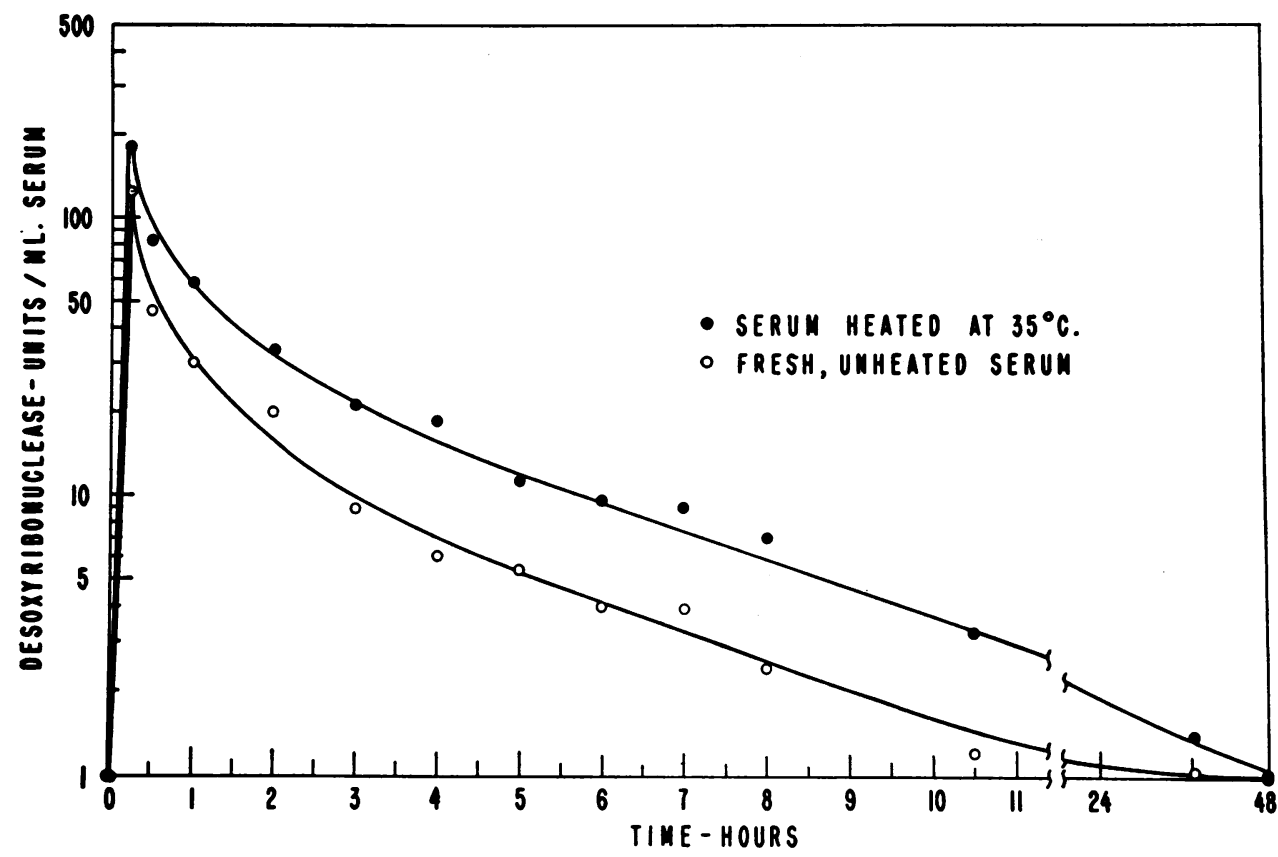

Fig. 2. Semi-Log Plot of the Serum Levels of PD as Determined on Heated and Unheated Sera before, during, aNd AFter the RAPId Intravenous INfusion of 1,000,000 Units of PD in a Patient 
the intravenous injection of $\mathrm{PD}$ was heated to $35^{\circ} \mathrm{C}$. for 5 to 10 hours the assay of $\mathrm{PD}$ was 30 to 60 per cent higher than for the unheated sera. The specific differences between measurements made on heated and unheated samples derived from a single patient are given in Figure 2.

Assays for PD on the unheated sera averaged about 45 per cent of the values for assays on the heated sera indicating about 55 per cent inhibition of the PD in the serum of this patient. This amount of inhibitor was corroborated by inhibitor and recovery studies performed on control samples in vitro.

The causes of the progressive decline in blood level of PD and the rate of this fall (Figure 2) are probably referable to several factors. Kurnick has described the sequestration, excretion, and metabolism of endogenous rat desoxyribonuclease by the intact rat liver (27). Observations of excretion and diffusion, to be subsequently described, indicate other routes by which PD may leave the general circulation.

\section{"Naturally" occurring inhibitor}

When sera containing added $\mathrm{PD}$ was heated for about 8 hours at $35^{\circ} \mathrm{C}$., complete recovery of the PD occurred. Recovery of the added PD from a few samples was accomplished after only 2 to 3 hours of heating at $35^{\circ} \mathrm{C}$., about 8 hours sufficed for most samples, while a few required as long as 10 to 15 hours. The heat lability of the PD inhibitor varied from patient to patient, and from specimen to specimen taken at one-halfhour intervals from the same patient. The reasons for this variability are not known. The concentration and type of cation in the plasma may play a role in stabilizing the inhibitor inasmuch as the inhibitor in plasma that was prepared by the ion-exchange method was resistant to heat inactivation for 10 to 15 hours, while the inhibitor in serum controls drawn at the same time was heat inactivated in two and one-half to three hours.

In the experiment detailed in Figure 3, $0.1 \mathrm{ml}$. of a neopeptone buffer solution containing 8.0 units of PD was added to $0.9 \mathrm{ml}$. of fresh, undiluted serum. The mixture was agitated gently and allowed to stand at room temperature for 15 minutes after which a sample was drawn for as-

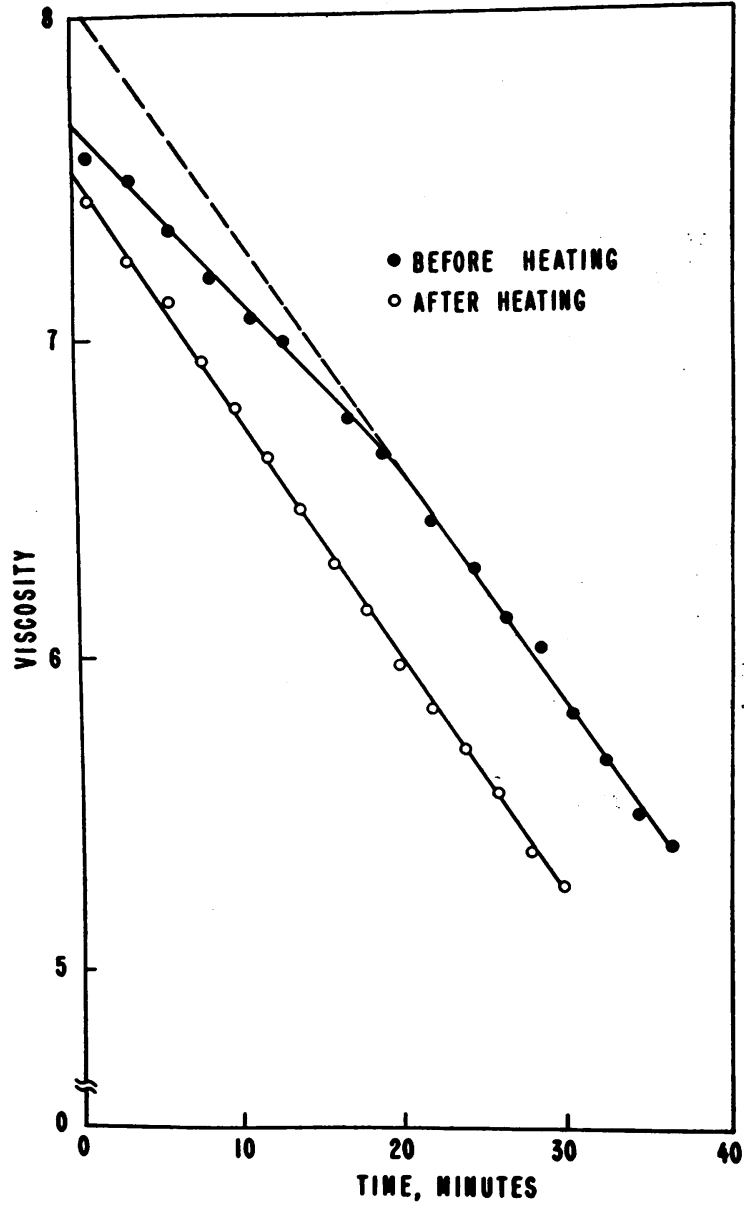

Fig. 3. Heat Inactivation of Serum Inhibitor FOR PD

The slope of the second part of the curve of the unheated serum was extrapolated to the $Y$ axis for purposes of comparison.

say. The mixture was then placed in the $35^{\circ} \mathrm{C}$ waterbath and incubated for 5 hours following which another sample was drawn for assay. In the assay on the unheated serum, the inhibition as indicated by the viscosity-time plot was most apparent in the first 15 minutes of the curve. During the next 5 to 10 minutes the inhibition gradually diminished and thereafter inhibition was nearly absent. Additional data suggest that the decrease in inhibition with time was due to dilution of the inhibitor by the large volume of substrate used in the assay with subsequent dissociation of a reversible inhibitor-enzyme complex. This was also emphasized by the fact that the slope of the second portion of the curve for the unheated 
TABLE I

Inactivation of serum inhibitor for $P D$ by heat

\begin{tabular}{lcc}
\hline \hline \multicolumn{1}{c}{ Serum } & $\begin{array}{c}\text { DNase units/ } \\
\text { ml. serum } \\
\text { units }\end{array}$ & $\begin{array}{c}\text { Inhibition } \\
\%\end{array}$ \\
\hline Before heating* & 4.6 & 43 \\
Heated 3 hours at $35^{\circ} \mathrm{C}$. & 5.9 & 26 \\
Heated 6 hours at $35^{\circ} \mathrm{C}$. & 6.4 & 20 \\
Heated 9 hours at $35^{\circ} \mathrm{C}$. & 7.8 & 3
\end{tabular}

* Eight units of PD were added to each ml. of serum at the beginning of the experiment.

sera was nearly parallel to the slope of the curve of the heated sera. In addition, the curve seen with fresh serum showing inhibition (Figure 3), was replaced by a straight line, without evidence of inhibition, after the sera was heated at $35^{\circ} \mathrm{C}$. for 5 hours. The recovery experiment in Table I shows the inactivation of serum inhibitor over a ninehour period. Following the addition of eight units of PD to $0.9 \mathrm{ml}$. of fresh serum, assays were performed on the mixture at 0 time and after 3,6 , and 9 hours incubation at $35^{\circ} \mathrm{C}$. As the heating was continued, the inhibitor was inactivated, and the per cent inhibition decreased gradually from 43 per cent to 3 per cent in 9 hours.

The inhibitor was destroyed by heating the sera at $56^{\circ}$ for 5 minutes before addition of the enzyme, by storage in the refrigerator for several months, storage at room temperature for several days, extremes of $\mathrm{pH}$, and the addition of trypsin. ${ }^{13}$ The inhibitor was maximally precipitated by ammonium sulfate at 40 per cent saturation and was not affected by dialysis, quick freezing and thawing, or storage at $-20^{\circ} \mathrm{C}$. for long periods of time. Because it was heat labile, non-dialyzable, and destroyed by trypsin the inhibitor was thought to be a protein or part of a protein complex. The inhibitor appeared to differ from those previously shown to be derived from white blood cells $(28-30)$ because it was present in equal

${ }^{13}$ Crystalline trypsin, Armour Laboratories.

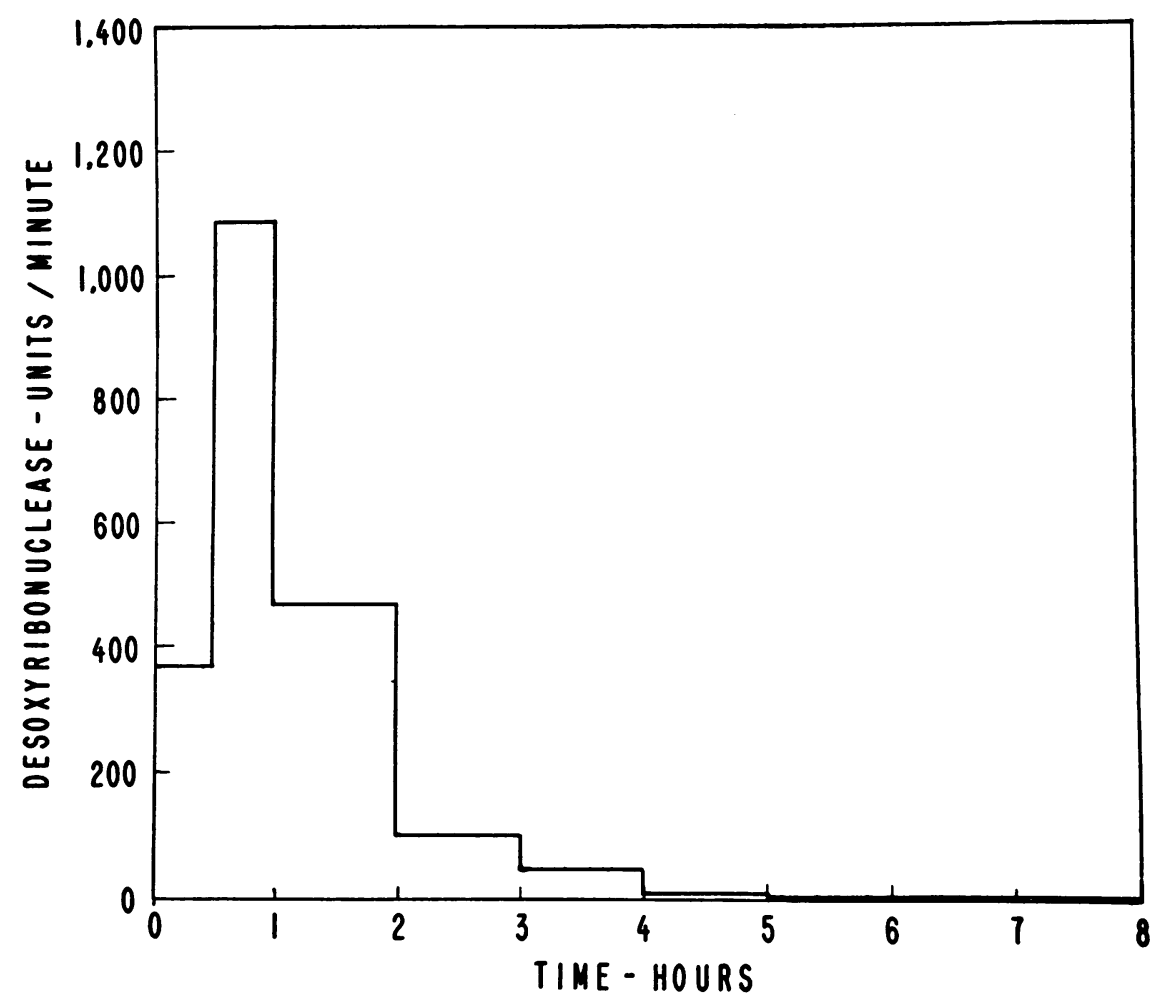

Fig. 4. URinary Excretion of PD Following the Intravenous Injection of $1,000,000$ Units over a Period of Thirty Minutes in a Patient without Renal Disease

The injection began at 0 time.

Eighty thousand five hundred units of PD were excreted in four hours. 
amounts in serum contaminated by cellular proteins, plasma free of white blood cells, and plasmawhite cell concentrates. The serum for this experiment was derived in the conventional manner from whole blood and inevitably contained soluble proteins from traumatized white blood cells; the plasma was decalcified by ion-exchange resin and centrifuged gently for at least one-half hour until it was free of white blood cells. The plasmawhite cell concentrates were obtained by differential centrifugation of the resin-treated plasma and from the heparinized blood of patients with infection whose white blood cell counts were above 30,000 per $\mathrm{cu} . \mathrm{mm}$. The concentrates were placed in the ice-box for three to four days in order to permit autolysis of the white blood cells. Release of the previously described inhibitor into the plasma supernatant was expected to accompany autolysis of the white blood cells, but no increase in non-specific inhibition was noted.

These experiments suggested that the inhibitor in human serum is not concentrated in the white blood cells (28-30). On the other hand, the properties of the inhibitor in human serum are consistent, in some respects, with those of a reversible inhibitor occurring in the soluble supernatant from tissue homogenates derived from the crop gland of brooding pigeons and bull testes (31-33).

\section{Renal excretion and clearance}

When $\mathrm{PD}$ was given intravenously, large amounts were excreted in the urine without demonstrable proteinuria or hematuria.

Thus, in a representative instance (Figure 4), during the intravenous infusion of $1,000,000$ units of $\mathrm{PD}$, the excretion of desoxyribonuclease in the urine rose from a pre-injection level of 15 units per minute to 360 units per minute in thirty minutes. One-half hour after the infusion was completed the urinary excretion of $\mathrm{PD}$ reached a maximum of 1,090 units per minute and fell, thereafter, to approximately control levels within the ensuing 5 to 6 hours.

When a total dose of 10,000 to $1,000,000$ units was given in thirty minutes or less, 5 to 10 per cent of the injected dose was regularly recovered in the urine. However, when the same dosage was given over four hours, as much as 20 per cent of the injected dose was excreted in the urine.

Inasmuch as a majority of these determinations were made during a falling plasma level of $P D$, several experiments were conducted by the constant infusion technique with a sustained plasma level.

In this experiment (Figure 5) 100,000 units of $\mathrm{PD}$ were injected intravenously at zero time and 800,000 units were infused at a constant rate of 5,000 units per minute for 160 minutes. A rea-

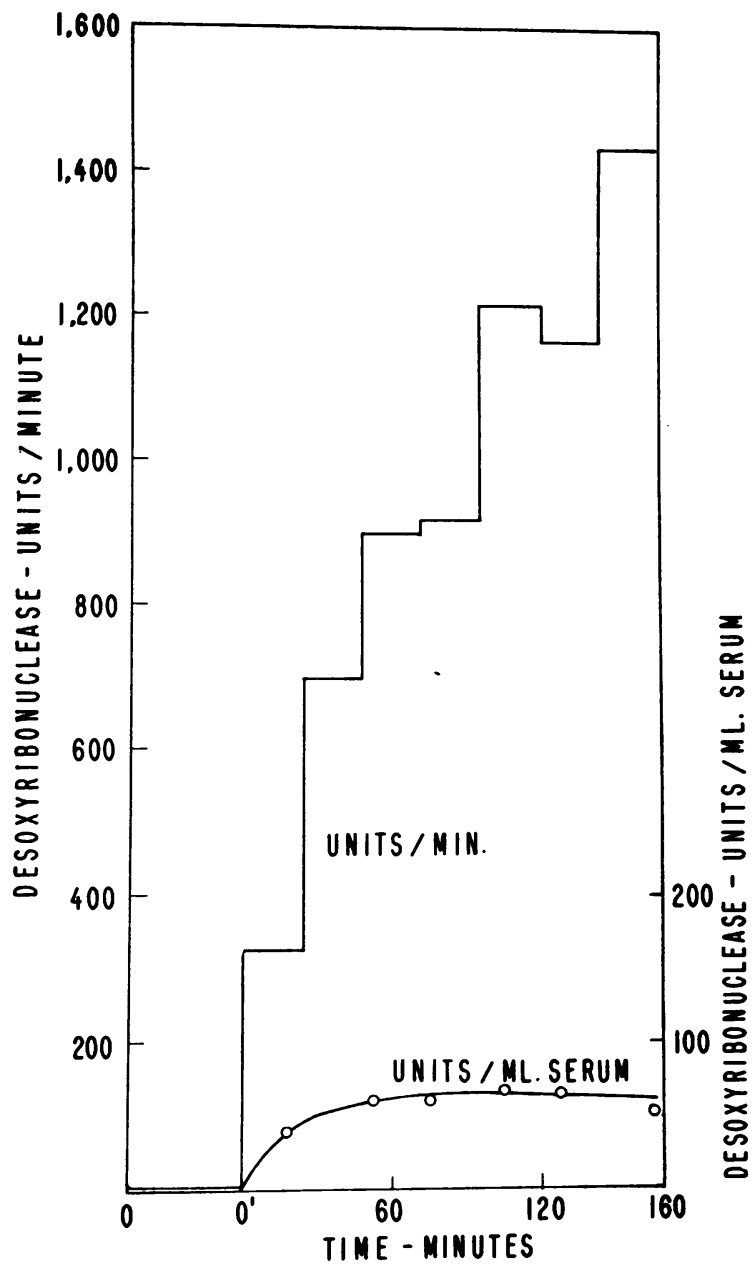

Fig. 5. URINARY EXCRETION OF PD BEFORE AND DURing THE Constant Intravenous Infusion of 800, 000 Units of PD over a Period of 160 Minutes in A Patient without Renal Disease

$0-0^{\prime}$ represents a control period. At $0^{\prime}$ the constant intravenous infusion was started at a rate of 5,000 units per minute and a priming dose of 100,000 units was injected within 2 minutes. 


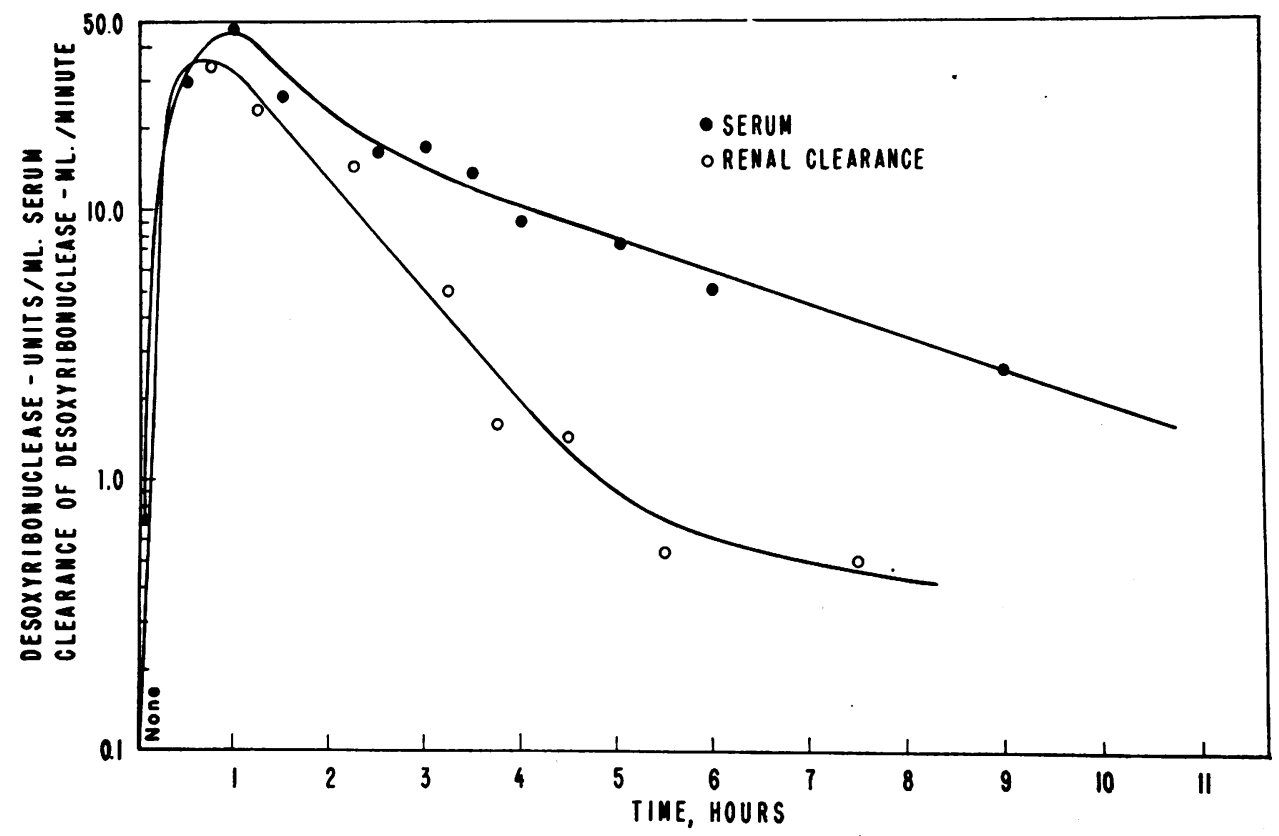

Fig. 6. Renal Clearance of PD Following a Single Intravenous Injection of 1,000,000 Units in a Patient without Renal Disease

sonably constant level of $\mathrm{PD}$ in the serum was reached in 50 minutes. In spite of this, the urinary excretion rose continuously during the entire infusion period.

The average of 12 clearance periods obtained on four patients without renal disease who had received constant infusions of $\mathrm{PD}$ was $17 \mathrm{ml}$. per minute, while the range was 13 to $27 \mathrm{ml}$. per minute. For purposes of comparison the clearance of a protein of a similar molecular size, albumin, in patients with nephrosis has been reported to be 0.5 to $1.0 \mathrm{ml}$. per minute $(34)$.

Renal clearances of PD were obtained in 11 other patients who were given a single injection of $1,000,000$ units of $\mathrm{PD}$ over a relatively short period of time without a sustaining infusion. In a typical experiment (Figure 6) the clearance periods were run before, during, and after the infusion of $P D$, and may be seen to rise and fall with the level of PD in the serum.

However, comparing the clearance data on a large number of patients, there seemed to be little or no correlation between the clearance of $\mathrm{PD}$ and the level of PD in the serum, or the urine flow.

Glomerular filtration, tubular reabsorption and/ or tubular excretion were considered as possible mechanisms for the excretion of PD.

$\mathrm{PD}$ is a protein of the albumin type with a molecular weight of approximately 60,000 (3). It is recognized that crystalline proteins like $P D$ may not be completely uniform in molecular size and configuration. Nevertheless, the high molecular weight of $\mathrm{PD}$ and the low clearances, compared to inulin, mitigate against simple glomerular filtration. Further, if some glomerular filtration did occur, the rising excretory rate of PD at a constant serum level would make a constant reabsorptive process unlikely, but would not rule out a variable rate of reabsorption by the tubules. It is possible that PD may be reversibly bound by the serum proteins, thus complicating the interpretation of the mechanism or mechanisms of renal excretion. It is also possible that PD may be actively excreted by the renal tubular cells, and the rate of excretion may, in turn, depend upon the duration of the infusion and the subsequent "loading" of the tubular cells. Further studies on the mechanism of renal excretion are in progress.

In view of the large amounts of $\mathrm{PD}$ found to be excreted in the urine, $1,000,000$ units of PD were given intravenously to an 86 year old female, Z. P., with profoundly purulent urine due to cystitis. No antibiotics were given. The photograph in Figure 7 shows the urine before the intravenous injection of $P D, 7$ hours after, and 24 
hours post-injection, and illustrates the striking effect of high concentrations of $P D$ in the urine on desoxyribose nucleoprotein present in purulent urine and in the urinary tract. The effect in this patient was transitory and the exudate started to return in 24 hours. The potentialities of the treatment of urinary infections will be subsequently considered in the discussion.

Endogenous desoxyribonuclease in the urine of man. Desoxyribonuclease was found to be present in samples of normal urine in amounts rang- ing from 0.5 to 15 units per $\mathrm{ml}$. of urine. In the present study the urinary PD was not considered to be of bovine origin unless the concentration in the urine was at least 3 to 5 times the pre-injection level.

Diffusion of intravenously injected $P D$ into serous cavities and wounds

1. Diffusion of $P D$ into ascitic fluid. Five patients with ascites due to cirrhosis of the liver were studied.

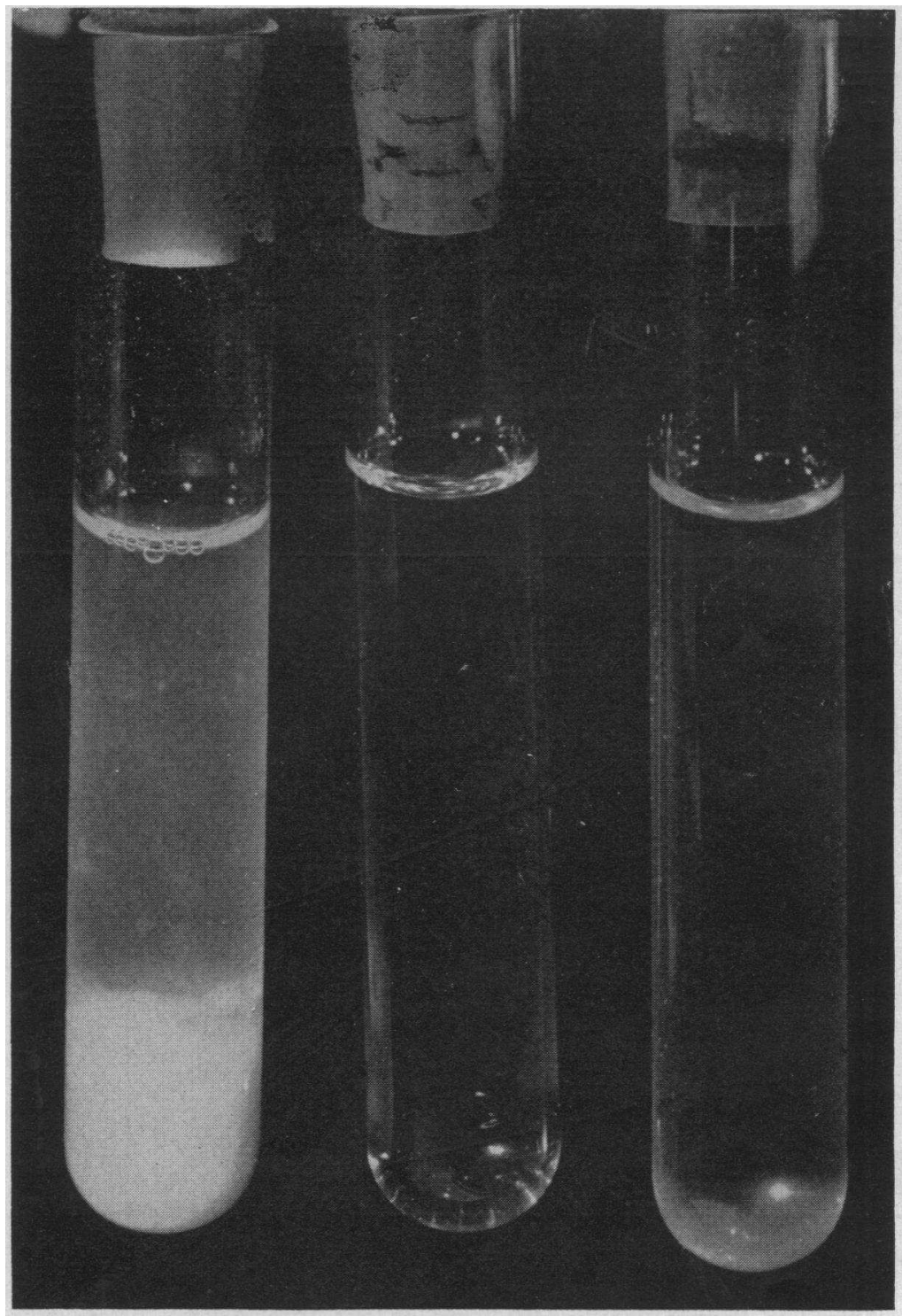

Fig. 7. Effect of a Single Intravenous Injection of $1,000,000$ Units of PD in a Patient with Purulent Cystitis

The urine samples were taken before the injection of PD, 7 hours after, and 24 hours post-injection. 
In a representative patient given a single intravenous injection of $1,000,000$ units of $P D$ (Figure 8 ) the abrupt rise and fall of PD in the serum is paralleled by a similar, but lesser rise and fall in the amount of PD in the ascitic fluid. The rise of $\mathrm{PD}$ in the ascitic fluid usually started about 30 minutes following the intravenous injection, reached a maximum in 3 hours, which varied in different patients studied from 0.2 to 1.0 units per $\mathrm{ml}$. and persisted at lower levels ( 0.1 to 0.2 units per ml.) for at least 24 hours. One patient showed a persistent low level of PD ( 0.2 units) in the ascitic fluid for 5 days without measurable amounts in the serum.

2. Diffusion of $P D$ into pleural effusions. Four patients with pleural effusions have been studied.

In a representative patient with tuberculous pleural effusion the intravenous injection of one million units of $P D$ resulted in a rise and then fall in the serum level with a similar rise of PD in the pleural fluid (Figure 9). However, fluctuations occurred in the level of $\mathrm{PD}$ in pleural fluid obtained from two different sites which were probably separated by pleural adhesions, inasmuch as there were also marked differences in the character of the fluid obtained from them. Eight hours after the infusion, the level of PD in the pleural fluid was higher than the blood level (Figure 9).

The maximum level of $\mathrm{PD}$ in the pleural fluid varied considerably, and ranged from 0.1 to 1.9 units per ml. in the four patients studied. The amount of PD recoverable from the pleural fluid, as well as the duration over which PD was recoverable seemed to vary inversely with the amount of purulent exudate present. In two cases with relatively small amounts of exudate, 0.1 to 0.2 units of PD per $\mathrm{ml}$. were found in the pleural fluid 24 hours after the intravenous injection. In the other two patients with large amounts of purulent pleural exudate, no PD was evident 24 hours post-injection. This was thought to be due to the large amounts of substrate (DNA) in the purulent exudates.

One patient with a 3-week history of severe cough and chest pain had, on admission to the hospital, a pneumococcal pneumonia, Type III, complicated by an empyema and a fever of $102^{\circ}$. The empyema fluid was thick, green and markedly purulent. Penicillin and 1,000,000 units of

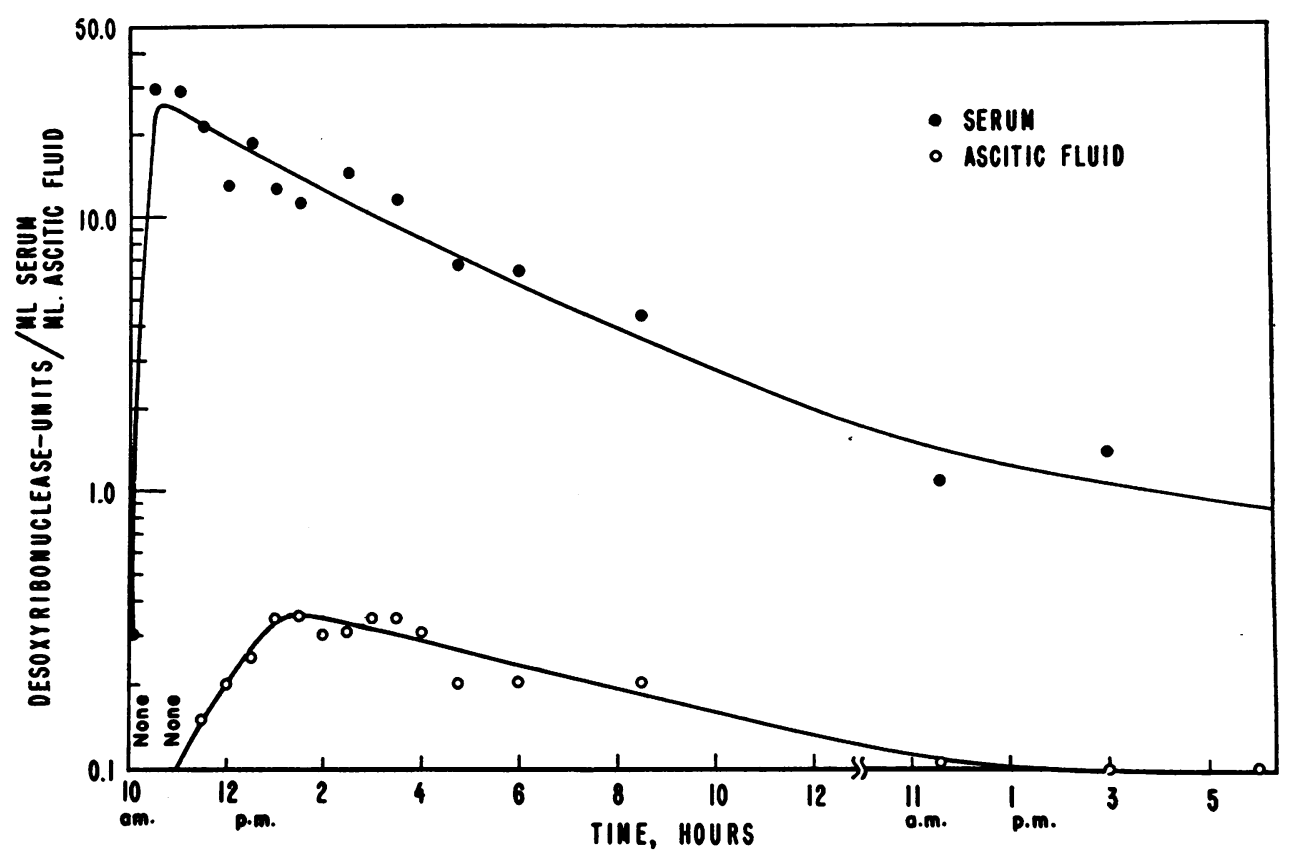

Fig. 8. Semi-Log Plot Showing Diffusion of PD into Ascitic Fluid Following a Single Intravenous Injection of $1,000,000$ Units of PD in 10 Minutes in a Patient With LaEnNeC's Cirrhosis

The injection was started at 10:00 A.M. 


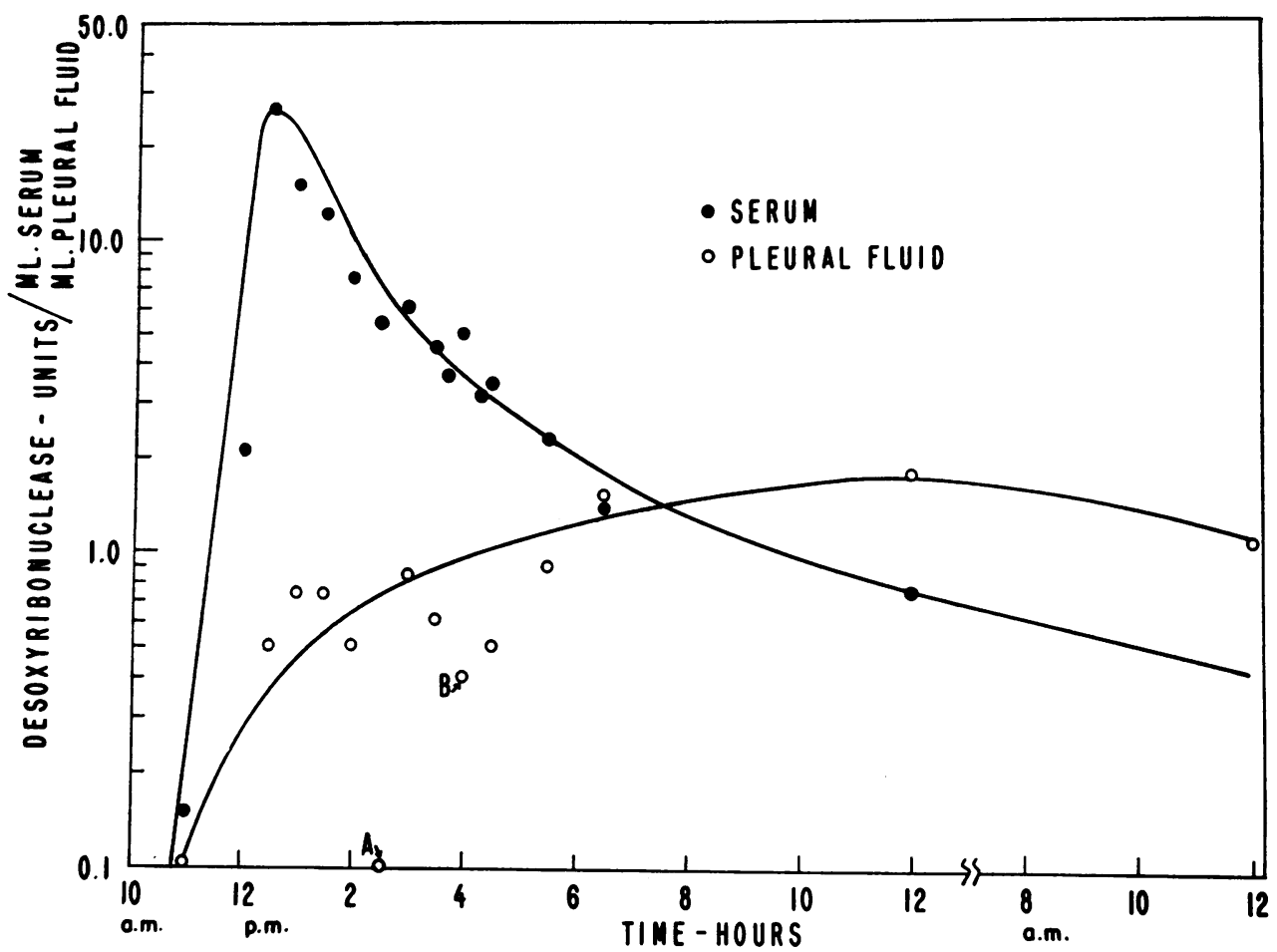

Fig. 9. Semi-Log Plot Showing Diffusion of PD into Pleural Fluid Following a Single Intravenous Injection of $1,000,000$ Units of PD in 10 Minutes in a Patient with Tuberculous Pleural Effusion

The injection was started at 11:30 A.M.

$A$ and $B$ represent two different empyema pockets.

PD were given intravenously. Within 48 hours the patient's clinical condition improved markedly, his temperature returned to normal, and the empyema fluid became thinner but still contained many white blood cells. Three days later the empyema fluid was thin, straw-colored, sp. gr. 1012, with a marked reduction in white blood cells. The findings suggest a correlation between the diffusion of PD into the empyema and rapid clinical improvement.

3. Diffusion of $P D$ into wound exudates. Two patients who had fresh granulating wounds without evidence of suppurative infection or excessive diapedesis of red blood cells were studied. One patient had a leg ulcer, the other a deep nephrectomy wound. The wounds were sealed with a rubber dam using tincture of benzoin as a rubber cement on the skin and rubber dam. Samples of exudate were taken by washing the wound surface with $1 \mathrm{ml}$. of saline before and 8 hours after the intravenous injection of $1,000,000$ units of PD. No desoxyribonuclease was present in the washings from the leg ulcer before injection, while 0.1 of a unit per $\mathrm{ml}$. was found before injection in the drainage from the nephrectomy wound. About 8 hours post-injection there was 0.6 of a unit per $\mathrm{ml}$. in the washings from the leg ulcer and 1.6 units per $\mathrm{ml}$. in the washings from the nephrectomy wound.

The diffusion of intravenously injected $P D$ into tissue fluids was demonstrated by measurements made on edema fluid obtained by Southey tubes inserted into the legs of a patient with cardiac failure. The level of PD in the edema fluid started to rise about one-half hour after the rapid injection of $1,000,000$ units of $\mathrm{PD}$, reached a maximum of 0.6 of a unit in about 3 hours, and fell to normal ( 0.05 units) in about 10 hours.

4. Diffusion of $P D$ into bronchial secretions. Three patients with bronchiectasis and markedly purulent sputum were studied. The bronchiectasis was secondary to chronic lymphatic leuke- 
mia with mediastinal adenopathy in one patient, to delayed resolution of pneumonia in another and to chronic bronchopneumonia in the third, an 8-year-old child with probable cystic disease of the pancreas. The mean of 7 samples of sputum taken from the three patients before the enzyme was administered was 0.3 units per $\mathrm{ml}$. with a range of 0.1 to 0.4 units per $\mathrm{ml}$. The mean value of 11 samples taken following the intravenous injections of PD was 0.75 units per $\mathrm{ml}$. with a range of 0.1 to 3.2 units per $\mathrm{ml}$. Cytochemical observations on these sputa with the Feulgen stain indicated complete depolymerization of the extracellular DNA in some specimens, inconsistent results in others. It remains to be determined whether the dosage of PD will have to be increased or repeated at more frequent intervals to obtain maximal depolymerization of purulent material in the sputum. Furthermore, respiratory mucin has been shown to exert a protective action on the desoxyribonucleoprotein in the sputum (35) and excessive amounts of mucin may limit the effectiveness of the PD excreted into the bronchial area.

It has been reported that partially purified $\mathrm{PD}$, given for therapeutic purposes by inhalation to patients with chronic bronchiectasis and purulent sputum $(35,36)$ induced definite depolymerization of the DNA in the sputum with moderate clinical improvement. In 23 cases of uncomplicated purulent bronchitis the administration of $2.5 \mathrm{mgm}$. of crystalline PD in gelatin buffer by inhalation induced a striking but transitory reduction in the viscosity of purulent sputum, lasting for about 12 hours. When the purulent sputum assumed a mucoid state before the enzyme was given, no change in viscosity followed inhalation of PD. The authors conclude that the volume of sputum, cytochemical observations, bronchospirometer studies, and clinical evaluation of the experimental and control groups failed to reveal a significant difference between treated and untreated groups, probably due to inadequate dosage. They also felt that the protective effect of respiratory mucin may have prevented adequate mixing or contact of the enzyme (PD) and the substrate (desoxyribonucleoprotein) present in the purulent sputum. Consequently, a respiratory mucinase should be used in conjunction with PD in cases where the respiratory mucin is very high in viscosity.

5. Diffusion into cerebro-spinal canal. Since the blood-brain barrier is resistant to the passage of large molecules it was of interest to determine whether measurable quantities of $\mathrm{PD}$ could be recovered from the cerebro-spinal fluid following the intravenous injection of PD. The content of endogenous DNase in 25 normal cerebro-spinal fluids was found to average 0.05 of a unit per ml.

Intravenous injections of $1,000,000$ units of PD were given to 19 patients and the DNase levels determined on the cerebro-spinal fluid from 40 lumbar punctures at varying intervals following the injections (Table II). The PD in the cerebro-spinal fluid of three of six patients with normal meninges, 2 to 6 hours following the injection, varied from 0.1 to 0.4 units per $\mathrm{ml}$. at the fourth or fifth hour, and declined irregularly thereafter to pre-injection levels within the subsequent 24 hours. The average amount of PD recovered from the cerebro-spinal fluid of patients with meningitis was lower than that recovered from the cerebro-spinal fluid of normal individuals. It appears probable that the same type of combination of enzyme and substrate (DNA) occurred in meningitic exudation as in the pleural fluids already discussed.

This assumption was supported by the observation that 5 to 15 units per $\mathrm{ml}$. of $\mathrm{PD}$ were found in the cerebro-spinal fluid of normal individuals 24 hours after the injection of 50,000 units intrathecally. In patients with meningitis, only 1 to 5 units of PD per $\mathrm{ml}$. were found in the cerebro-spinal fluid 24 hours after intrathecal injection, when the cerebro-spinal fluid white blood cell counts were below 10,000 per $\mathrm{mm}^{3}$. No PD was found at the 24-hour period in the cerebro-spinal fluid of patients with more than 15,000 white blood cells per $\mathrm{mm}^{3}$.

Patients with tuberculous meningitis complicated by cerebro-spinal fluid block are being treated by both intravenous and intrathecal injections of PD. In two out of three instances the block was relieved as demonstrated by manometric and X-ray studies, and in one instance by autopsy. When sufficiently comprehensive information has been obtained relative to the problem of block, especially in tuberculous meningitis, the results will be reported in a separate communication. 


\section{Antibody formation}

Streptodornase has been reported to induce the formation of specific antibodies in patients who received Varidase ${ }^{\circledR}$ (streptokinase-streptodornase) for the treatment of local purulent exudations (7). Antibody determinations were performed on sera from 12 normal controls and 7 patients selected at random from those who had received single injections of 500,000 to $1,000,000$ units of PD. The samples of sera in the patient group were obtained 7 to 21 days after the injection of PD. Although methods similar to those previously employed ( 7 ) were used no antibody was found.

In addition, sera were examined from each of the six patients mentioned previously who had received a total of $60,000,000$ units of $P D$. One child had been given about 1,500,000 units of $\mathrm{PD}$ in two intravenous injections and 16 intrathecal injections over a period of two months. Serum samples were taken at the end of the first month, second month, fifth month, and seventh month. No antibody was found. All the other patients in this group received a minimum of $5,000,000$ units of PD over varying periods of time ranging from 5 to 45 days. Serum samples were obtained from these patients one to four weeks following the last injection. In one instance a titre of 40 antibody units was obtained, and in two other instances titres of about 5 to 10 units were found. The sera from the other three patients in this group contained no antibody. Specificity of the antibody was indicated inasmuch as $\mathrm{PD}$ was neutralized by the anti-serum after the sera was heated at $56^{\circ} \mathrm{C}$. for as long as 10 hours, thus excluding the action of natural inhibitor. Furthermore, the heat stable antibody was concentrated in the gamma globulin fraction of the serum by ammonium sulfate fractionation. This antibody showed no cross-reactivity with $\operatorname{SD}(7,37)$.

The evidence indicates, therefore, that the crystalline enzyme employed is a relatively poor antigen in man when injected by the intravenous or intrathecal route. The low antigenicity of PD when injected intravenously in rabbits has been reported (6). Variations in the quantity of protein required for effective antigenicity are well known. According to determinations in this laboratory the specific activity of $\mathrm{PD}$ is about 600 units $/ \gamma \mathrm{N}$, or approximately $11 \mathrm{mgm}$. of crystalline protein $/ 1,000,000$ units of PD. For comparative purposes the subcutaneous injection of $0.5 \mathrm{mgm}$. of purified diphtheria toxoid protein is effective as a primary antigen in man.

\section{Potential therapeutic implications}

The rationale of the possible therapeutic usefulness of $P D$ rests upon the results of previous studies of streptococcal desoxyribonuclease (contained in Varidase ${ }^{\circledR}$ ), and the similarity of the enzymatic action of PD and streptococcal desoxyribonuclease.

The identification of desoxyribose nucleoprotein (DNA-P) as a significant constituent of purulent exudations which frequently accounts for their thick, viscid physical characteristics (38), initiated and broadened the studies of streptococcal enzymes in therapy of which SD is a significant component $(39,40)$.

It is unnecessary to review again the details of the mechanism by which SD promotes recovery except to point out that the basic features of its therapeutic usefulness are immediately dependent upon the thinning and destructive effect of the enzyme on the viscous DNA-P $(41,42)$. Previous reports on the effectiveness of SK-SD (Varidase $^{\circledR}$ ) in the local treatment of purulent infections (43-45) have been amply confirmed. (For recent references see footnote 14 to list of References.)

In considering the two enzymes, $\mathrm{PD}$ and $\mathrm{SD}$, the partially purified preparations of SD have been reported to contain several nucleolytic enzymes by which DNA is extensively split with the ultimate liberation of free purine bases (46). On the other hand, PD splits DNA only to the level of tetra-nucleotides $(4,47)$. In both instances, degradation has occurred to the level of acid-soluble, dialyzable fragments.

When, in the present studies, it was demonstrated that $\mathrm{PD}$ exhibited the unusual capacity both of renal excretion and diffusion into various extravascular areas following intravenous injection, it became evident that local areas of disease not easily accessible for topical application of the enzyme might be reached via the intravenous route. 
TABLE II

$P D$ in the cerebro-spinal fluid of twelve patients with normal meninges, and six with meningitis at varying time intervals following the injection of 1,000,000 units intravenously

\begin{tabular}{|c|c|c|}
\hline $\begin{array}{c}\text { Time* } \\
\text { (hours) }\end{array}$ & $\begin{array}{l}\text { DNase in } \\
\text { spinal fluid } \\
\text { (units) }\end{array}$ & $\begin{array}{l}\text { Patients with normal } \\
\text { meninges (N), or } \\
\text { meningitis }(\mathbf{M})\end{array}$ \\
\hline 0 & 0.05 & $\begin{array}{c}\text { Average pre-injection } \\
\text { level on all patients } \\
\mathrm{N} \text { and } \mathrm{M} \text {. } \\
\text { Range } 0.0-0.15\end{array}$ \\
\hline $\begin{array}{l}2 \\
2\end{array}$ & $\begin{array}{l}0.2 \\
0.1\end{array}$ & $\begin{array}{l}\mathbf{N} \\
\mathbf{N}\end{array}$ \\
\hline 4 & 0.1 & $\mathrm{~N}$ \\
\hline $\begin{array}{l}5 \\
5 \frac{1}{2}\end{array}$ & $\begin{array}{l}0.4 \\
0.4\end{array}$ & $\begin{array}{l}\mathbf{N} \\
\mathbf{N}\end{array}$ \\
\hline 6 & 0.1 & $\mathbf{N}$ \\
\hline $\begin{array}{l}7 \\
7\end{array}$ & $\begin{array}{l}0.05 \\
0.10\end{array}$ & $\begin{array}{l}\mathbf{N} \\
\mathbf{M}\end{array}$ \\
\hline 12 & 0.0 & $\mathbf{N}$ \\
\hline $13 \frac{1}{2}$ & 0.1 & $\mathrm{~N}$ \\
\hline 15 & 0.1 & $\mathbf{N}$ \\
\hline $\begin{array}{l}24 \\
24 \\
24 \\
24 \\
24\end{array}$ & $\begin{array}{l}0.2 \\
0.0 \\
0.1 \\
0.1 \\
0.0\end{array}$ & $\begin{array}{l}\mathbf{M} \\
\mathbf{M} \\
\mathbf{N} \\
\mathbf{N} \\
\mathbf{M}\end{array}$ \\
\hline $\begin{array}{l}48 \\
48\end{array}$ & $\begin{array}{l}0.0 \\
0.0\end{array}$ & $\begin{array}{l}\mathrm{M} \\
\mathbf{M}\end{array}$ \\
\hline
\end{tabular}

* Time (hours) indicates time after the intravenous injection when sample of spinal fluid was obtained.

Since some of the patients employed in the present investigation suffered from diseases for which local dornase therapy might be indicated, the fact that PD reached the area in an enzymatically active state and caused depolymerization of the local collections of DNA-P is of considerable interest. The patient with cystitis (Figure 7) is a striking example of the mechanism just outlined. In some of the other patients with either empyema, purulent bronchitis or meningitis, the intravenously injected PD reached the site of disease and exhibited transient local activity. Further studies directed primarily toward the development of the optimal method of utilizing PD therapeutically, particularly by intravenous injections, are now in progress.

\section{SUM M ARY}

1. The intravenous injection of bovine crystalline pancreatic desoxyribonuclease into man in doses up to $2,000,000$ units, evoked no demon- strable toxic reactions either general, local, or of the hematopoietic system.

2. The introduction of the enzyme intrathecally into adults and children with normal meninges, in an average dose of 50,000 units was accompanied by slight changes in the cytology and total protein of the cerebro-spinal fluid. An occasional transient reduction in the cerebro-spinal fluid pressure was also noted. No irritative effect was observed following intrathecal injections of $\mathrm{PD}$ into patients with meningitis.

3. The blood level one hour following an intravenous injection of $1,000,000$ units averaged about 30 units per $\mathrm{ml}$. of serum and fell to near normal values within 24 hours.

4. The measured level of pancreatic desoxyribonuclease in the serum was found to be partially dependent upon the amount of an inhibitor for PD present in the circulating blood of the patients. The inhibitor proved to be a heat labile, non-dialyzable protein that combined reversibly with $\mathrm{PD}$ in a readily dissociable complex.

5. Pancreatic desoxyribonuclease in an active form was excreted in the urine following its injection intravenously in patients. Following rapid injections, about 8 per cent of the intravenous dose was excreted 10 to 12 hours post-injection. The renal excretion of this protein of the albumin type presents certain unusual aspects which have been discussed.

Endogenous desoxyribonuclease was also found to be excreted in the urine of normal individuals.

6. Intravenously injected pancreatic desoxyribonuclease diffused readily into the peritoneal and pleural fluids, wound exudates, and bronchial secretions. A dosage of $1,000,000$ units gave a range of diffusion of 0.1 to 3.2 units per $\mathrm{ml}$. The enzyme also diffused into the cerebro-spinal fluid, but in smaller amounts and with some irregularity.

7. In 13 patients serologically studied, no specific antibody was demonstrable in 10 ; in the remaining 3 patients, only low titres occurred.

8. The potential therapeutic implications associated with the unusual excretion and diffusion of pancreatic desoxyribonuclease are discussed.

\section{ACKNOWLEDGMENT}

The authors wish to acknowledge the capable technical assistance of Miss Lillian Gong and Mr. Jack Newman. 


\section{REFERENCES 14}

1. Johnson, A. J., and Goger, P. R., The intravenous injection into patients of crystalline pancreatic desoxyribonuclease. Its excretion in the urine and its distribution in certain body fluids. J. Clin. Invest., 1953, 32, 579 (Abstr.).

2. Kunitz, M., Isolation of crystalline desoxyribonuclease from beef pancreas. Science, 1948, 108, 19.

3. Kunitz, M., Crystalline desoxyribonuclease. I. Isolation and general properties. Spectrophotometric method for the measurement of desoxyribonuclease activity. J. Gen. Physiol., 1950, 33, 349.

4. Kunitz, M., Crystalline desoxyribonuclease. II. Digestion of thymus nucleic acid (desoxyribonucleic acid). The kinetics of the reaction. J. Gen. Physiol., 1950, 33, 363.

5. Christensen, L. R., Methods for measuring the activity of components of the streptococcal fibrinolytic system, and streptococcal desoxyribonuclease. J. Clin. Invest., 1949, 28, 163.

6. McCarty, M., Purification and properties of desoxyribonuclease isolated from beef pancreas. J. Gen. Physiol., 1946, 29, 123.

7. Hazlehurst, G. N., Anti (streptococcal) desoxyribonuclease. Occurrence in the sera of patients treated with streptococcal concentrates containing streptodornase. J. Immunol., 1950, 65, 85.

8. Johnson, A. J., and Tillett, W. S., The lysis in rabbits of intravascular blood clots by the streptococcal fibrinolytic system (streptokinase). J. Exper. Med., 1952, 95, 449.

9. Sherry, S., Johnson, A., and Tillett, W. S., The action of streptococcal desoxyribose nuclease (streptodornase), in vitro and on purulent pleural exudations of patients. J. Clin. Invest., 1949, 28, 1094.

10. Stefanini, M., Purification of the resin amberlite IR-100 for blood coagulation studies. Proc. Soc. Exper. Biol. \& Med., 1948, 67, 22.

11. Gilbert, L. M., Overend, W. G., and Webb, M., The inhibition of pancreas deoxyribonuclease. Exptl. Cell Research, 1951, 2, 349.

12. Wintrobe, M. M., Clinical Hematology, 3rd ed., Philadelphia, Lea and Febiger, 1951, pp. 262 and 256.

13. Shapiro, S., Weiner, M., Luddecke, H. F., Kroc, R. L., and White, E. J., A simply prepared, standardized, and relatively stable thromboplastin extract for estimation of prothrombin time. Am. Heart J., 1950, 40, 766.

14. Mathis, H. B., A simple office procedure for demonstrating lupus erythematosus cells in peripheral blood. Blood, 1951, 6, 470.

14 For comprehensive review of recent articles on clinical use of Varidase (streptokinase-streptodornase), see bibliography contained in: "Recent advances in Varidase therapy" distributed by Lederle Laboratories Division, American Cyanamid Co., 30 Rockefeller Plaza, New York $20, N$. Y.
15. Magath, T. B., and Winkle, V., Technic for demonstrating "L.E." (lupus erythematosus) cells in blood. Am. J. Clin. Path., 1952, 22, 586.

16. Kingsbury, F. B., Clark, C. P., Williams, G., and Post, A. L., The rapid determination of albumin in urine. J. Lab. \& Clin. Med., 1926, 11, 981.

17. Hawk, P. B., Oser, B. L., and Summerson, W. H., Practical Physiological Chemistry, 12th ed., London, J. A. Churchill, Ltd., 1947, p. 520.

18. Hawk, P. B., Oser, B. L., and Summerson, W. H., Practical Physiological Chemistry, 12th ed., London, J. A. Churchill, Ltd., 1947, p. 814.

19. Eagle, H., and Harris, T. N., Studies in blood coagulation: V. The coagulation of blood by proteolytic enzymes (Trypsin, Papain). J. Gen. Physiol., 1937, 20, 543.

20. Tagnon, H. J., Effect of intravenous injection of trypsin on the blood coagulation time in hemophilia. Proc. Soc. Exper. Biol. \& Med., 1944, 57, 45.

21. Kurnick, N. B., The determination of desoxyribonuclease activity by methyl green; application to serum. Arch. Biochem., 1950, 29, 41.

22. Klemperer, P., Gueft, B., Lee, S. L., Leuchtenberger, C., and Pollister, A. W., Cytochemical changes of acute lupus erythematosus. Arch. Path., 1950, 49, 503.

23. Kurnick, N. B., Pariser, S., Schwartz, L. I., Lee, S. L., and Irvine, W., Studies on desoxyribonuclease in systemic lupus erythematosus. Nonparticipation of serum desoxyribonuclease in the "L.E. phenomenon." J. Clin. Invest., 1952, 31, 1036.

24. Wróblewski, F., and Bodansky, O., Presence of desoxyribonuclease activity in human serum. Proc. Soc. Exper. Biol. \& Med., 1950, 74, 443.

25. Kurnick, N. B., Desoxyribonuclease activity of sera of man and some other species. Arch. Biochem. \& Biophys., 1953, 43, 97.

26. Zamenhoff, S., Personal Communication.

27. Kurnick, N. B., and Carrera, A. E., Reduction in plasma desoxyribonuclease activity on circulation through the liver: index of liver function. Proc. Soc. Exper. Biol. \& Med., 1953, 84, 618.

28. Henstell, H. H., and Freedman, R. I., The viscosimetric determination of desoxyribonuclease inhibition. Cancer Research, 1952, 12, 341.

29. Henstell, H. H., Freedman, R. I., and Ginsburg, B., An inhibitor of desoxyribonuclease in human white blood and bone marrow cells, and its relationship to cellular maturity. Cancer Research, 1952, 12, 346.

30. Kurnick, N. B., Schwartz, L., Pariser, S., Lee, S., and Irvine, W., The role of desoxyribonuclease and a nuclease inhibitor from leucocytes in the lupus erythematosus cell phenomenon. J. Clin. Invest., 1952, 31, 645

31. Dabrowska, W., Cooper, E. J., and Laskowski, M., A specific inhibitor for desoxyribonuclease. $\mathrm{J}$. Biol. Chem., 1949, 177, 991. 
32. Cooper, E. J., Trautmann, M. L., and Laskowski, M., Occurrence and distribution of an inhibitor for desoxyribonuclease in animal tissues. Proc. Soc. Exper. Biol. \& Med., 1950, 73, 219.

33. Laskowski, M., Personal Communication.

34. Chinard, F. P., Lauson, H. D., Eder, H. A., Greif, R. L., and Hiller, A., A study of the mechanism of proteinuria in patients with the nephrotic syndrome. J. Clin. Invest., 1954, 33, 621.

35. Elmes, P. C., and White, J. C., Deoxyribonuclease in the treatment of purulent bronchitis. Thorax, 1953, 8, 295.

36. Armstrong, J. B., and White, J. C., Liquefaction of viscous purulent exudates by deoxyribonuclease. Lancet, 1950, 2, 739.

37. McCarty, M., The inhibition of streptococcal desoxyribonuclease by rabbit and human antisera. $\mathrm{J}$. Exper. Med., 1949, 90, 543.

38. Sherry, S., Tillett, W. S., and Christensen, L. R., Presence and significance of desoxyribose nucleoprotein in the purulent pleural exudates of patients. Proc. Soc. Exper. Biol. \& Med., 1948, 68, 179.

39. Tillett, W. S., Sherry, S., and Christensen, L. R., Streptococcal desoxyribonuclease: Significance in lysis of purulent exudates and production by strains of hemolytic streptococci. Proc. Soc. Exper. Biol. \& Med., 1948, 68, 184.

40. McCarty, M., The occurrence of nucleases in culture filtrates of group A hemolytic streptococci. J. Exper. Med., 1948, 88, 181.
41. Tillett, W. S., and Sherry, S., The effect in patients of streptococcal fibrinolysin (streptokinase) and streptococcal desoxyribonuclease on fibrinous, purulent, and sanguinous pleural exudations. J. Clin. Invest., 1949, 28, 173.

42. Tillett, W. S., Studies on the enzymatic lysis of fibrin and inflammatory exudates by products of hemolytic streptococci. Harvey Lectures, Series XLV, 1949-50, Charles C Thomas, 1952, p. 149.

43. Tillett, W. S., Sherry, S., and Read, C. T., The use of streptokinase-streptodornase in the treatment of postpneumonic empyema. J. Thoracic Surg., 1951, 21, 275.

44. Tillett, W. S., Sherry, S., and Read, C. T., The use of streptokinase-streptodornase in the treatment of chronic empyema, with an interpretive discussion of enzymatic actions in the field of intrathoracic diseases. J. Thoracic Surg., 1951, 21. 325.

45. Sherry, S., and Tillett, W. S., The local use of streptokinase-streptodornase in chronic refractory areas of suppuration with draining sinuses. Ann. Surg., 1952, 135, 479.

46. Sherry, S., and Goeller, J. P., The extent of the enzymatic degradation of desoxyribonucleic acid (DNA) in purulent exudates by streptodornase. J. Clin. Invest., 1950, 29, 1588.

47. Carter, C. E., and Greenstein, J. P., Studies on the enzymatic degradation of nucleic acids. J. Nat. Cancer Inst., 1946, 7, 29. 